\title{
Accent: A literature review of English Language Variation on Sociolinguistics
}

\author{
Nur Aeni M \\ Universitas Negeri Makassar, Indonesia
}

Muthmainnah

Universitas Al Asyariah Mandar, Indonesia

Like Raskova Octaberlina

Universitas Islam Negeri Maulana Malik Ibrahim, Malang, Indonesia

Nenni Dwi Aprianti Lubis

Universitas Sumatera Utara, Indonesia

ARTICLE INFO

Keywords

- What is Accent?

- Nonnative pronunciation

- Common Kind of Accent

- Types of British Accent

- Accent Discrimination

- Foreign accent syndrome

\section{ABSTRACT}

This paper discusses the sense of Accent. This article offers a summary of the various recognizable shifts in the pronunciation of local dialects and the general variations in the standard English of different primary speaking populations. Accent is the component of the local pronunciation dialect. Grammar and vocabulary are otherwise mentioned. Secondary speakers of English prefer to use their mother tongue's intonation and phonetics in English speaking. The English primary speakers exhibit great regional diversity. Some of them are easily recognized by key features, such as Pennsylvania Dutch English; others are darker or more ambiguous. Broad regions may have sub-forms, as shown below. For example, cities less than 10 miles $(16 \mathrm{~km})$ away from Manchester city, such as Bolton, Rochedale, Oldham, and Salford have distinct accents that all together form part of the larger accents of the province of Lancashire. Australia has a "General accent" emphasis on the other side of the continuum, which is basically consistent in tens of miles. The accents of English can differ enough to give room for misunderstanding. In certain varieties of Scottish English, for example, the pronunciation of pearl can sound like petal to an American ear.

\section{INTRODUCTION}

As human beings spread out into isolated communities, stresses and peculiarities develop. Over time these can evolve into recognizable accents. The presence of people from many ethnic groups in North America led to the creation of North American accents in different species. The time it takes to formulate an accent is difficult to quantify or forecast. Accents, for example, have formed from variations of different accents and languages in different cultures in the USA, Canada or Australia and have had an influence on various British colonial pronunciations.

In certain instances, non-English colonists from the British Isles had a very different effect on the accents of the different colonies. The vowel pronunciation in some parts of Australia and Canada was substantially impacted by immigrants from Ireland, Scotland or Welsh. In phonetics, the accent of the property of a syllable that varies from its next syllables. The focus on the accented syllable in comparison to the non-accented syllables can be realized by a larger duration, higher or lower pitch, shifts in pitch outline, a greater loudness, etc.

Accent has different fields: phrase, sentence and sentence. Term accent is part of the characteristic way that a language is pronounced (also called word stress or lexical stress). Given a specific language structure, a word accent can be fixed, or predictable (e.g. in the English where regular at the end of words occurs, or in the Czech language in original cases) or mobile, as in the English language, which enables an accent to differentiate the same word from the other word (e.g., the noun permit versus the verb permit). 


\section{A. What is Accent?}

In sociolinguistics, the focus is on the way in which a particular person, place or nation is pronounced. An accent can be placed on where its speakers are located (a geographical or regional emphasis), on the socioeconomic role of the speakers, on their race, on their grades, on their first language (imperfectly speaking a second language), etc.

Accents usually vary for voice tone, vowel- and consonant-division, stress and prosody-division. While grammar, sémantics, vocabulary and other language features frequently vary in tone with emphasis, the word 'accent' may directly refer to pronunciational differences, while the word 'dialect' includes a wider range of linguistic differences. 'Accent' is also a 'dialect' sub-set.

An emphasis is a way to speak a language. Therefore without an accent it is difficult to speak. Some may think that they have no emphasis. Or you might think there are those who have no accent. All of us have an emphasis. Often the word "accent" is used by non-language people, who are associated with people from a very large area and people of the highest social class, to talk of one of the high-prestige 'reference' accents (for example 'General American' or, less often, 'RP'). There are accents, however.

Your focus is on how, where, and when you have mastered the language, which gives other people an idea of you. There is no fixed accent on people which is based on their experiences. We can influence and control how we speak, both consciously and unconsciously. Most people differ based on who they talk to. Often without warning, we change our accents as we live with new experiences.

It depends not just on the characteristics of your voice and who your audience is and what they know about other people who talk to you with similar emphasis.

Your accent could be related to people from a specific location (for example, with being from New York, London, or Delhi). You can only be heard by others as from the United States, England, or India. You may feel like that before the language you speak at the moment you spoke some other language (you might speak French with an English accent, or English with a Korean accent). You can't talk without giving your accent to some detail.

There are many different accents in every language. The English language is nothing special. And not everyone from the same place speaks the same thing: there are different accents everywhere. Over time, the vocabulary shifts. We get new words, grammatical changes are taking place and accents shift over time. If you hear recordings made 100 years ago by people in your language culture, you can hear that accentuations have changed even during that period.

\section{B. Nonnative pronunciation}

The language speakers who speak non-native English can show pronunciation characteristics resulting from their imperfect learning of the sonic system of English either by transferring phonological rules from their mother language into English ("interference") or by applying strategies which are similar to those used in primary language learning. They can also establish novel English pronunciations that are not present in the first language of the speaker.

The age when language speakers are starting to immerse themselves in a language (such as english) is linked to the degree to which Native speakers can sense non-native accents; and "neurological plasticity, cognitive development, motivation, psychosocial states, formal instruction, language learning aptitude" and the use of languages can influence the exact nature of the relation.

English is unique in that speakers are rarely able to audibly release consonants and sometimes overlap time constraints. Speaking English with a radically different timing pattern can lead to hardly understandable speech.

More specifically, differences in phonological distinctions between the first language of a speaker and English appear to neutralize such differences in English, and differences in the sound inventory or delivery can lead to native sound replacement instead of difficult English sounds and/or a straightforward deletion. This is more likely if the contrast between English sounds or between English and the primary language of a speaker is subtle. Although it should be noted that simple lack of a sound or sequence in the phonological inventory of a language makes it impossible to understand, a number of theoretical models assumed that non-native speech experiences represent both abstract phonological properties and native language phonetic information. 
Non-native pronunciations may be conveyed to student children who, while native speakers themselves, display some related characteristics. This method, for example, resulted in some of the distinguishing qualities of Irish English and Highland English strongly influenced by a Goidelic substratum.

\section{What types of Accent?}

Everyone has the opportunity to speak English. By what part of the world in which you live, everybody develops an English accent. You may not notice the people around you, but you will all over the world. In fact, the world over has 160 different English dialects. In predominantly English-speaking countries, such as the USA and England, there is a wide variety of accents and an extensive range of foreign English accents. However, in the present article, the author will clarify only those accents that are commonly used and very common from different parts of the world.

\section{British Accent}

British English (BrE), as spoken and written in the United Kingdom, is the standard English dialect. In the United Kingdom, there are changes in the official, written English. In areas of Scotland, North East England, Ireland, and even Yorkshire the word wee is practically exclusively used, for example, whereas there is nothing else in the country. However, in written English in the United Kingdom there is a large degree of uniformity, which could be defined in English. However, the types of spoken English differ much more than those in most other parts of the world in which the language is spoken, making it harder for the spoken language to apply a standard British English definition. In the Oxford Handbook on World English Tom McArthur notes that English "all the ambiguities and tensions in the word 'British' and as a result can be used and interpreted in two ways, more broadly or more narrowly, within a range of blurring and ambiguity"

2. American Accent

In fact English is the universal language used by the federal and national governments and is the most commonly used in the United States in so far as all legislation and binding education presume that English is the main language. 32 of the 50 state governments directly offer English official status. Although, under Federal Law, local courts in some US divisions grant English and other languages equal status — such as English and Spanish in Puerto Rico - English remains the official language for all matters referred to the United States District Court for the territory.

American English varieties include a variety of pronunciation patterns, vocabulary, grammar and particularly spelling unified across the country, but distinct from other English dialects worldwide. Any American or Canadian accent which is considered to be free of noticeably local, racial or cultural markers is popularly referred to as the American "General" or "Standard" The spectrum of emphasis is fairly homogeneous, originating from certain areas of the United States and is related to broadc However, the notion of a single American "mainstream" accent does not support historical and current linguistic evidence. The sound of American English keeps shifting, with some local accents gone but more local accents appeared in the twentieth century

3. Australian Accent

Australian English (AuE, AuEng) is Australia's native English variety. While English is not the language of the Constitution, Australian English, as the country's first language for the majority of the population, is the national and de facto official language.

After the First Settlers, who founded the colony in New South Wales, arrived in 1788, Australian English started to diverge from British English. By 1820, their speech was known to be different from English. Australian English emerged from the intermingling of early settlers from various dialectal regions of GRI and the UK, and soon developed into a distinct variety of English in vocabulary, accent, pronunciation, register, grammar and orthographer, that differed greatly from most other varieties of English.

4. Irish Accent

Hiberno-English is the collection of English dialects, natively written and spoken in Ireland (from Latin Hibernia: "Ireland") or Irish (Ulster-Scots: Erse Inglis, irish: Béarla na hÉireann) (including both the Republic of Ireland and Northern Ireland)

The Norman invasion of Ireland in the late 12th century introduced English to Ireland. In the 16th century Elizabethan, the second wave of the English language in Ireland was translated as the oldest English spoken outside of Britain and phonologically more conservative than Elizabethan English in the 16th century. In the beginning, the language of Norman-English had been spoken mainly in a region known as The Pale, in the area around Dublin. The English of the time remained mostly in small pockets of speakers, who evolved in late (nowextinct) English variants, known in Wexford as Yola and in Fingal, Dublin as a result of their pure isolation. These dialects were known as Yola. This with other English varieties were no longer mutually intelligible. By the Tudor, the Irish culture and language had re-established much of the land which had been lost by those invaded: "all the common folk... for the most part are of Irish birth, Irish habit, and of Irish language" 
However, the conquest and colonization of Tudor by Ireland in the 16th century led, along with the forced suppression and decline, to the second wave of immigration by English speakers. The majority language spoken in the country was English at the middle of the 19th century. It has maintained the status until today, even for those who speak Irish as their first language. Today, little more than $1 \%$ of the population speaks the Irish language natively, but it must be taught in all government-sponsored schools. Of the $40 \%$ who described themselves as some Irish speakers in 2016, 4\% speak Irish everyday outside the education system. English is one of two official languages in the Republic of Ireland (along with Ireland) and is the de facto working language of that region.

\section{What types of British accent?}

You can imagine balance, sophistication and royalty when thinking about the British. You can also combine the English with films you are used to. Men with the fine emphasis of Hugh Grant and the easily understood queen's English are impeccably well-managed. You don't actually remember Professor Henry Higgins of My Fair Lady who spoke a great deal.

Well, if you touch British soil, what you have in mind might come as a shock. You will be bombarded with accents you do not know. Nothing close to your idea of the UK English you learnt in school or were exposed to. It might be confusing or even completely disconcerting, because it can't even sound English remotely. This is because Great Britain is very rich in dialects with countless historical accents. To prevent you from being caught off guard, some of the popular accents are here, to get to know you:

1. Geordie

As the oldest English dialect still spoken, Geordie normally refers to both the people and dialect of NewcastleUpon-Tyne in Northeast England. Don't worry if you find this accent difficult to understand at first, as many other Brits also struggle. Geordie Brit Cheryl Cole came close to starring in the US version of the X-Factor but was dropped from the show as no one could understand what she was saying.

To prevent you looking completely confused, here are a few words that you might hear when speaking to a Geordie:

"Canny", pronounced "CAH-ne", meaning good, nice, true.

"Gan", meaning to go, such as "We're gan doon the road."

"Doon" means down.

2. Cockney

Commonly spoken in East London, the cockney accent is also used to refer to anyone from London. Cockney is also described as anyone within earshot of the church bells of St. Mary-le-Bow in the city of London.

3. Multicultural London English (MLE)

This London-based accent, known as a sociolect, is a dialect specific to a particular social class and predominantly heard among young people. If you find yourself wondering the streets of Hackney in London, you might come across the following terms:

"Blud" meaning mate.

"Ends" refers to a neighbourhood or geographical area.

"Bare" is used to mean very or lots of which might be confusing as it is used in standard English to mean sparse or uncovered.

4. Scottish English

Scots roll their Rs regularly and collapse their words so that they sound like they have been cut off in the middle. For instance, 'cot' instead of 'caught' and 'not' with 'nee'. So instead of saying you 'didn't do anything in Edinburgh', it sounds more like 'didnee do anythin' in Ednbrah.' To get a feel for the accent, just think of the gorgeous Gerard Butler.

\section{West Country (Southwest British)}

The West Country accent can be heard in the South of England, just about fifty miles west of London and extending to the Welsh border. Often, the letter ' $r$ ' is pronounced after vowels. Instead of saying mother as 'muthah', someone from the Southwest would say 'mutherrr'. Look up Comedian Justin Lee Collins.

6. Midlands English

The most famous is Brummie English, spoken by people in the midland's city of Birmingham. Brummie has repeatedly been voted as the worst accent in the UK, despite the popularity of the British show Peaky Blinders. 


\section{Welsh English}

The accent is heavily influenced by the Welsh language. Although a survey has shown that some Welsh feel that their accent may prove to be a hindrance to their career, others remain proud and describe the accent as melodious and lilting. Watch the hit show Gavin \& Stacey to hear welsh English in natural conversation. Is it a yay or nay for you?

\section{Estuary English (Southeast British)}

Typically heard around Southeast England, Estuary English is commonly spoken by people who live along the river Thames and its estuary. However, it can also be found stretching beyond London to the regions of Essex and Kent. Estuary English is often described as a mix between cockney and Received Pronunciation (RP).

\section{E. Accent discrimination}

Discrimination means particular behaviors or actions aimed exclusively at a group or its individual members. In particular, the speech is used as a basis for arbitrary evaluations and rulings with regard to discrimination. There are no strong standards against the accent of discrimination in the general society, unlike other forms of discrimination. Writing from Rosina Lippi-Green,

Accent is the first point of gate keeping, as it is prohibited to use race, ethnicity, homeland or economy more immediately, by law and social custom and perhaps by a dominant sense of what is morally and ethically right. However, we have no such language compunctions. Accent thus becomes an excuse to turn away, to recognize the other person.

Housing and employment discrimination is often the case for speakers with certain accents. For instance, speakers with foreign or racial minority focus are less likely than those with standard accents to be requested by landlords and are more likely to be assigned lower status by the employer. People with non-standard accents are more likely to be assessed negatively in business settings. In educational institutions, too, accent discrimination is present. For example, students who are not speaking mother tongue, lecturers and teachers across universities across the USA were targeted because their accent was not understood.[In average, students who were taught English by other non-mother tongues are not under-represented compared to those taught by mother tongue speakers.

Studies have shown that the accent is perceived, not the accent alone; often the speakers are negative. Students heard a tapped lecture by the same native English speaker with a standard accent in a study conducted by Rubin (1992). However, a picture of the speaker who was a Caucasian or Asian was displayed. Students who saw the Asian scene thought they heard an accentuated lecturer and did a worse job of measuring the understanding of the lecture. Instead of real problems with understanding, negative evaluations can reflect the prejudices

\section{F. Foreign accent syndrome}

Foreign Accent Syndrome (FAS) is a speech disorder that changes the voice suddenly to a foreign speaker. FAS is the voice disorder. Brain damage caused mostly by a stroke or traumatic brain injury is caused by FAS. Multiple sclerosis and conversion disorders were reported as well, and in some cases no clear cause was identified.

The timing, intonation, and placing of the tongue can alter the speech sounding foreign. Speech remains highly understandable and doesn't sound disordered necessarily.

FAS is documented in worldwide cases including accent changes from English to French, Japanese to Korean, English to French, English to English to British and Hungarian to Spanish.

Some common FAS-related speech changes include:

- Fairly predictable errors

- Unusual prosody, including equal and excess stress (especially in multi-syllabic words)

- Consonant substitution, deletion, or distortion

- Voicing errors (i.e. bike for pike)

- Trouble with consonant clusters

- Vowel distortions, prolongations, substitutions (i.e. "yeah" pronounced as "yah")

- "uh" inserted into words 
Accent has different fields: phrase, sentence and sentence. Term accent is part of the characteristic way that a language is pronounced (also called word stress or lexical stress). Given a specific language structure, a word accent can be fixed, or predictable (e.g. in the English where regular at the end of words occurs, or in the Czech language in original cases) or mobile, as in the English language, which enables an accent to differentiate the same word from the other word (e.g., the noun permit versus the verb permit). Children are relatively quick to acknowledge. For example, children of immigrant families usually have a native pronunciation more than parents, although both children and parents have a significant nonNative emphasis, but they usually have differences: their parent's accent is influenced generally by their native language sound systems, while the child is more likely to have a hyperpronunciation as a result of the need. Nevertheless, even in adulthood accents are not fixed. An acoustic review of the Royal Christmas Messages of Elizabeth II by Jonathan Harrington showed that the style of speech of a queen, even if so Conservative, will continue to evolve over her lifetime.

\section{Bibliography}

Dudley-Evans, T., and M. J. St. John, Developments in English for Specific Purposes, Cambridge: Cambridge University Press, 1998.

Graves,K. Designing Language Course. Boston:Heinle\& Heinle,2000.

Hutchinson, T., and A. Waters, English for Specific Purposes: A learning-centred Approach, Cambridge: Cambridge University Press, 1987.

Harmer, Jeremy, The Practice of English Language Teaching, London: Longman, 1991.

Day, H. and Krzanowski, M. (2011). Teaching English for Specific Purposes: An Introduction.Cambridge, UK. Cambridge University Press.

Munby, J., Communicative Syllabus Design, Cambridge: Cambridge University Press, 1987.

Richard, Jack C., Communicative Language Teaching Today, Cambridge University Press, 2006.

Robinson, P., ESP (English for Specific Purposes), Pergamon, 1980.

Strevens, P., ESP after twenty years: A re-appraisal, In M. Tickoo (Ed.), ESP: State of the art (1-13). SEAMEO Regional Language Centre, 1988.

Sysoyev, P., Developing an English for Specific Purposes Course Using a Learner Centered Approach: A Russian Experience, The Internet TESL Journal, Vol. VI, No.3, March 2000 http://iteslj.org/, 2000.

$\begin{array}{lllll}\text { Azazel, } & \text { CHAPTER } & \text { 7APPROACHES } & \text { TO COURSE } & \text { DESIGN, }\end{array}$ https://espeed2016.blogspot.com/2016/06/chapter-7-approach-to-course-design.html/ January, 12,2021)).

Asrifan, A. (2009). Using songs in teaching English language for the young learners. ParePare: unpublished.

Puasa, K., Asrifan, A., \& Chen, Y. (2017). Classroom Talk in Bilingual Class Interaction. Research in Pedagogy, 7(1), 106121.

Nadirah, N., Tahir, M. H., \& Asrifan, A. (2019). THE ABILITY TO TRANSLATE ENGLISH PHRASES INTO INDONESIAN AND THE DIFFICULTIES FACED BY THE ELEVENTH GRADE STUDENTS OF SMAN 1 PANCARIJANG. JOURNAL OF ADVANCED ENGLISH STUDIES, 2(1), 41-46.

Apdy, A. P. R., \& Asrifan, A. (2019, April). The Chinese mime game in teaching vocabulary on EFL classroom. In PROCEEDINGS OF THE 65th TEFLIN INTERNATIONAL CONFERENCE (Vol. 65, No. 01).

Taslim, T., Asrifan, A., Chen, Y., \& Nurdania, N. R. (2019). CORRELATION BETWEEN STUDENT'S VOCABULARY MASTERY AND SPEAKING SKILL. JOURNAL OF ADVANCED ENGLISH STUDIES, 2(2), 65-76.

Muthmainnah, M., Asrifan, A., Al Yakin, A., \& Sahabuddin, C. (2019, April). The use of dictogloss technique on ELT classroom: An experiment study of students listening comprehension. In PROCEEDINGS OF THE 65th TEFLIN INTERNATIONAL CONFERENCE (Vol. 65, No. 01).

Mutmainnah, M., Azis, S., Maulidya, U., \& Asrifan, A. (2017). Glory Style in Mandar Song Lyrics: A study of Mandar Tribe in South Sulawesi, Indonesia. JOURNAL OF ADVANCES IN LINGUISTICS, 8(1), 1286-1291.

Asrifan, A., Rinantanti, Y., Tang, S., \& Nadirah, N. (2019). THE 3-DIMENSION PICTURES IN INCREASING THE STUDENTS ABILITY AND INTEREST TO WRITE DESCRIPTIVE COMPOSITION. JOURNAL OF ADVANCED ENGLISH STUDIES, 2(1), 19-30.

Asrifan, A., Nadira, N., \& Haedar, H. (2018). IMPROVING STUDENTS'READING COMPREHENSION OF DESCRIPTIVE TEXT THROUGH COLLABORATIVE MURDER. JOURNAL OF ADVANCED ENGLISH STUDIES, 1(2), 21-31.

Asrifan, A. (2015). Analysis of English Students' Learning Style in Bilingual Class. International Journal of Literature and Arts, 3(4), 34 .

Farahdiba, S., \& Asrifan, A. (2016). Speaking Ability and Psychological Barriers of the Second Year Students of Hotel Department of SMKN 1 Sidenreng Kabupaten Sidrap in Speaking English. Asian EFL Journal, (89), 41.

Asrifan, A. (2012). Increasing the Students Ability to Write Descriptive Composition at SMP Negeri 13 Parepare by using the 3-Dimension Pictures.

Tang, S., Asrifan, A., Chen, Y., Haedar, H., \& Agussalim, M. (2019). THE HUMOR STORY IN TEACHING READING COMPREHENSION. JOURNAL OF ADVANCED ENGLISH STUDIES, 2(2), 77-87.

Nurwanti, N., Asrifan, A., \& Haedar, H. (2019). THE APPLICATION OF COOPERATIVE LEARNING: JIGSAW II TECHNIQUE IN IMPROVING STUDENTS'READING COMPREHENSION OF EXPOSITORY TEXT. JOURNAL OF ADVANCED ENGLISH STUDIES, 2(1), 31-40. 
Asrifan, A. (2016). The Effectiveness of Think-Pair-Share Technique in Improving Studentsâ€ $€^{\text {TM }}$ Speaking Ability and Interest. English Literature and Language Review, 2(3), 24-35.

Asrifan, A., Muthmainnah, M., Al-Yakin, A., Sahabuddin, C., \& Haedar, H. (2018). THE CAUSE-EFFECT TECHNIQUE IN TEACHING RECOUNT WRITING. JOURNAL OF ADVANCED ENGLISH STUDIES, 1(2), 63-72.

Asrifan, A., Vargheese, K. J., Syamsu, T., \& Amir, M. (2020). ESP COURSE DESIGN: THE NEED ANALYSIS ON TOURISM DEPARTMENT IN INDONESIA VOCATIONAL HIGH SCHOOLS. JOURNAL OF ADVANCED ENGLISH STUDIES, 3(2), 69-77.

Asrifan, A., Ghofur, A., \& Azizah, N. (2020). Cheating Behavior in EFL Classroom (A Case Study at Elementary School in Sidenreng Rappang Regency). OKARA: Jurnal Bahasa dan Sastra, 14(2), 279-297.

Nadirah, N., Asrifan, A., Vargheese, K. J., \& Haedar, H. (2020). INTERACTIVE MULTIMEDIA IN EFL CLASSROOM: A STUDY OF TEACHING READING COMPREHENSION AT JUNIOR HIGH SCHOOL IN INDONESIA. JOURNAL OF ADVANCED ENGLISH STUDIES, 3(2), 131-145.

Muthmainnah, A. R., Atmowardoyo, H., Salija, K., \& Asrifan, A. (2020). Literary Work as Teaching Materials: A Study of Students and Lecturers Needs Analysis. Solid State Technology, 63(5), 394-407.

Tilome, A. A., Agustang, A., Jasruddin, M. S., \& Asrifan, A. (2020). Social Exchange of Political Elites in the Regional Leader Election of Gorontalo Province, Indonesia. Solid State Technology, 63(5), 521-531.

Pacinongi, A., \& Asrifan, A. (2020). Bimbingan Pengawas Berkelanjutan dalam Mewujudkan Pendidikan Karakter Bangsa dalam Kegiatan Belajar Mengajar Penjaskes. Celebes Education Review, 2(1), 1-7.

Gunawan, G., \& Asrifan, A. (2020). Penerapan Kerja Kelompok Kegiatan MGMP Guru Ekonomi dalam Menyusun RPP untuk Meningkatkan Kompetensi Pedagogik. Celebes Education Review, 2(1), 31-36.

Yusuf, I., \& Asrifan, A. PENINGKATAN AKTIVITAS KOLABORASI PEMBELAJARAN FISIKA MELALUI PENDEKATAN STEM DENGAN PURWARUPA PADA $\quad$ SISWA $\quad$ KELAS XI IPA SMAN 5 YOGYAKARTA. Editorial Team, 32.

Al Yakin, A., Sahabuddin, C., Rahayu, A., Fitrah, N., \& Arifin, M. (2020). Political Celebrification and Electability: A Study of Political Phenomena Imaging in Election Polewali Mandar District, West Sulawesi, Indonesia. Solid State Technology, 63(5), 632-646.

Junaedah, S. B. T., \& Ahmad, M. A. (2020). The Outdoor Learning Modules Based on Traditional Games in Improving Prosocial Behaviour of Early Childhood. International Education Studies, 13(10).

Octaberlina, L. R., \& Muslimin, A. I. (2020). Efl students perspective towards online learning barriers and alternatives using moodle/google classroom during covid-19 pandemic. International Journal of Higher Education, 9(6), 1-9.

Octaberlina, L. R., \& Anggarini, I. F. (2020). Teaching vocabulary through picture cards in Islamic Elementary School: a case study in Nida Suksa School, Thailand. Jurnal Madrasah, 13(1), 26-38.

Octaberlina, L. R. (2016). Plagiarism in English language theses in Indonesia. Jurnal Ilmu Pendidikan, 14(3).

Octaberlina, L. R., \& Anggarini, I. F. (2020). Teaching vocabulary through picture cards in Islamic Elementary School: a case study in Nida Suksa School, Thailand. Jurnal Madrasah, 13(1), 26-38.

Asrifan, A., Zita, C. T., Vargheese, K. J., Syamsu, T., \& Amir, M. (2020). THE EFFECTS OF CALL (COMPUTER ASSISTED LANGUAGE LEARNING) TOWARD THE STUDENTS'ENGLISH ACHIEVEMENT AND ATTITUDE. JOURNAL OF ADVANCED ENGLISH STUDIES, 3(2), 94-106.

Asrifan, A. (2021). ACADEMIC WRITING. LawArXiv. January, 2. https://doi.org/10.31228/osf.io/x2s7e

Asrifan, A. (2020). TUTORIAL PENGGUNAAN QUIZIZZ (www. quizizz. com) PADA PEMBELAJARAN. https://doi.org/10.31219/osf.io/kqnza

Asrifan, A. (2021). Abd Ghofur.". THE USE OF READING CIRCLES IN INCREASING STUDENTS SPEAKING ABILITY AT THE ELEVENTH GRADE SMK NEGERI, 1. https://doi.org/10.31219/osf.io/8vjxy

Asrifan, A. (2020). Pandemic, Humanity and Education. https://doi.org/10.31219/osf.io/q2gpk

Asrifan, A. (2021). USING CAT AND MOUSE GAME TO IMPROVE STUDENT'S SPEAKING ABILITY AT THE ELEVENTH GRADE OF MA YMPI RAPPANG. https://doi.org/10.31219/osf.io/phtvn

Asrifan, A., \& Ghofur, A. (2021). THE USE OF READING CIRCLES IN INCREASING STUDENTS SPEAKING ABILITY AT THE ELEVENTH GRADE SMK NEGERI 1 PANCARIJANG. https://doi.org/10.31219/osf.io/8vjxy

Asrifan, A. (2021). Book Review: Halliday. 1989. Spoken and Written Language. Oxford University Press. https://doi.org/10.31219/osf.io/ej8tb

Asrifan, A., \& Ghofur, A. (2021). TALK, ACTION, SILENCE, INTERRUPTION AND THEIR IMPLICATIONS IN BUGINESE SOCIETY (SOPPENG REGENCY). https://doi.org/10.31219/osf.io/pv3ku

Asrifan, A. (2020). PENILAIAN BERBASIS ANDROID MENGGUNAKAN APLIKASI PLICKERS. https://doi.org/10.31219/osf.io/htreq

Haulussy, R. H., Najamuddin, I. R., \& Agustang, A. D. M. P. (2020). The sustainability of the Sasi Lola tradition and customary law (Case study in Masawoy Maluku, Indonesia). Intl J Sci Technol Res, 9(2), 5193-5195.

Arwan, A., Agustang, A., Arlin, A., Yani, A., \& PUTRA, D. M. (2019). Contestation of Elite Discourse in Treatment of HIV and AIDS. Iranian Journal of Public Health, 48(12), 2205.

Mutiara, I. A., Agustang, A., Adam, A., Upe, A., \& Equatora, M. A. (2020). The dynamics of prostitutes lives in metropolitan cities. Journal of Critical Reviews. https://doi. org/10.31838/jcr, 7, 165.

Usman, A., Agustang, A., Djalal, D., \& Annas, S. (2018, October). The Contribution Of Supporter Community In Maximizing Their Role For The Advancement Of Makassar Football Club (PSM). In 1st International Conference on Social Sciences (ICSS 2018). Atlantis Press.

Ma'na, P., Agustang, A., Salusu, J., Ikhsan, A., \& Dirawan, G. D. (2015). Decision making strategic value based local wisdom Tongkonan North Toraja. Man India, 95(3), 633-639.

Dirawan, G. D. FOSTERING COLLABORATION STREET CHILDREN IN MAKASSAR. Man In India, 95(3), 569-576.

Abdurachman, A. D. M. P. A., \& Agustang, A. Culture Of Shame-Heart And Social Solidarity Of Kaitetu People Central 
Maluku District, Indonesia.

Aida, K. N., Agustang, A., Arlin, A., \& Agustang, A. D. M. The Patron-Client Relationship Patterns In Siwa Lima Fishermen Community, Aru Islands District Maluku, Indonesia.

Pannyiwi, R., Agustang, A., Kasnawi, T., Pada, A. T., Yani, A., \& Syam, S. (2020). Social Network for Drug Circulation in Sidenreng Rappang Regency, Indonesia. Systematic Reviews in Pharmacy, 11(9), 575-577.

Upe, A., Salman, D., \& Agustang, A. (2019). The effects of the exploitation of natural resources towards risk society construction in Southeast Sulawesi Province, Indonesia. Journal of Degraded and Mining Lands Management, 6(2), 1587.

Matakena, F., Watloly, A., Agustang, A., Adam, A., \& Alim, A. (2020). The Self-Concept of Ale Rasa Beta Rasa in the Orang Basudara Community in Ambon (Studies on the Community of Passo and Batumerah Country). International Journal, 9, 1307.

Asmi, A. S., Kasnawi, M. T., Agustang, A., \& Yani, A. (2020). Sociocultural Transformation in Efforts to Reduce Mortality of Infants in Bone Regency, Indonesia. Systematic Reviews in Pharmacy, 11(10), 762-765.

Usmana, A., \& Agustangb, A. The Implementation of “Arif” Social Behaviour within Perssin Supporters in Sinjai District.

Hasan, I. R., Agustang, A., Kahar, F., \& Tahir, H. (2019). Super Service Delivery": an advanced conceptual model of onestop service for wide administrative region. Problems and perspectives in management, (17, Iss. 1), 189-201.

Asrifan, A. (2021). ISSUES IN TEFL “International Article Summary \& Presentation”: Students' Reactions to School Based Oral Assessment: Bridging the Gap in Malaysia. https://doi.org/10.31228/osf.io/te3m5

Asrifan, A., Al Yakin, A., \& Sahabuddin, C. The Use of Dictogloss Technique on ELT Classroom: An Experiment Study of Students Listening Comprehension.

Octaberlina, L. R., \& Asrifan, A. (2021). THE USE OF HUMOR STORY IN IMPROVING THE STUDENTS'READING COMPREHENSION. https://doi.org/10.31219/osf.io/kvsbe

Octaberlina, L. R., \& Asrifan, A. (2021). THE TEXT-BASED CHARACTER IN TEACHING READING COMPREHENSION AT THE TENTH GRADE STUDENTS. https://doi.org/10.31219/osf.io/p53sn

Asrifan, A. (2021). CODE MIXING AND CODE SWITCHING IN THE EFL CLASSROOM INTERACTION. https://doi.org/10.31228/osf.io/xd45c

Asrifan, A. (2021). ADVANCED GRAMMAR “Adverbs and Adverb Clauses”. https://doi.org/10.31228/osf.io/cuh83

Asrifan, A. (2020). TUTORIAL PENGGUNAAN QUIZIZZ (www. quizizz. com) PADA PEMBELAJARAN. https://doi.org/10.31219/osf.io/kqnza

Asrifan, A., \& Aeni, N. Book Review: I SPEAK FIVE LANGUAGES: FOSTERING PLURILINGUAL COMPETENCE THROUGH LANGUAGE AWARENESS By: Oliveira and Helena, Maria. https://doi.org/10.31228/osf.io/tjnq9

Asrifan, A. (2021). Modul Perkuliahan RESEARCH ON ENGLISH LANGUAGE TEACHING. https://doi.org/10.31219/osf.io/5rgvc

Asrifan, A. (2021). IMPROVING STUDENTS'SPEAKING ABILITY BY USING HAND DOLLS OF THE ELEVENTH GRADE STUDENTS OF MA YMPI RAPPANG. https://doi.org/10.31219/osf.io/zfhqu

Asrifan, A., Octaberlina, L. R., \& Handayani, R. (2021). SEMANTIC ANALYSIS ON THE USE OF ENGLISH LANGUAGE SLOGAN. https://doi.org/10.35542/osf.io/vtx5y

Asrifan, A. (2021). Book Review KONSTRUKSI GROUNDED TEORI Petunjuk Praktis Dalam Analisa Kualitatif Written By: Kathy Charmez. https://doi.org/10.31228/osf.io/nt8yk

Qisti, N., Nurwidah, A., Muslimin, I., \& Asrifan, A. (2020). THE EFFECT OF TEMPERATURE AND TIME DRYING TOWARD ORGANOLEPTIC QUALITY OF THE DUCKS BONE MEAL. Solid State Technology, 63(6), 1965219659.

Asrifan, A., \& Ghofur, A. Book Review: Writing for Academic Journals Second Edition. https://doi.org/10.31219/osf.io/su3ya

Andi Asrifan, N. (2020). THE TEXT-BASED CHARACTER IN TEACHING READING COMPREHENSION AT THE TENTH GRADE STUDENTS OF SMAN 4 SENRENG RAPPANG. Sarwah: Journal of Islamic Civilization and Thought, 18(02), 33-51.

Octaberlina, L. R., \& Asrifan, A. (2021). THE USE OF HUMOR STORY IN IMPROVING THE STUDENTS'READING COMPREHENSION.

Agustang, A., Mutiara, I. A., \& Asrifan, A. (2021). Genealogi Stigma Sosial Terhadap Pasien Covid 19. https://doi.org/10.31219/osf.io/ep7jf

Agustang, A., Ahriani, A., \& Asrifan, A. (2021). MARGINALISASI BUDAYA (STUDI PADA PRANATA SOSIAL MASYARAKAT MUSLIM SUKU KOKODA KOTA SORONG). https://doi.org/10.31219/osf.io/942y8

Agustang, A., Ariani, A. I., \& Asrifan, A. (2021). KONSTRUKSI SOSIAL JANDA TEREKSPLOITASI (STUDI KASUS DI KELURAHAN TETEBATU KECAMATAN PALLANGGA KABUPATEN GOWA).

Asrifan, A. (2021). APLIKASI DAN IMPLIKASI BERPIKIR SISTEMIK (SYSTEMIC THINKING) DALAM KEHIDUPAN.

Asrifan, A. (2021). PSIKOLOGI BELAJAR/TEORI BELAJAR: IMPLIKASI DAN HARAPAN.

Asrifan, A. (2021). PENDALAMAN MATA KULIAH SOCIOLINGUISTICS VARIASI SOSIAL PENGGUNA BAHASA.

Agustang, A. (2021). INTERAKSI SOSIAL KOMUNITAS LOKAL DENGAN PENDATANG DAN PERUBAHAN STRUKTUR KOMUNITAS LOKAL (Studi pada Masyarakat Majemuk di Kawasan Industri Makassar).

Agustang, A. (2021). KESEJAHTERAAN PSIKOLOGIS (studi Pada Dewasa Madya Yang Belum Menikah Di Kota Makassar).

Amelia, S., Lubis, N. D. A., \& Balatif, R. (2020). MIKROORGANISME DAN BAHAN PANGAN. Penerbit Qiara Media

Amelia, S., Lubis, N. D. A., Siregar, M. A., \& Rozi, M. F. (2018). Research Article Antimicrobial Effect of Wasabia japonica or Wasabi on Raw Salmon in Served Sashimi at Japanese Restaurants in Medan. 
Nasution, I. K., Lubis, N. D. A., Erwin, I., \& Nusa, M. I. (2018). Cognitive Function Differences based on Hemispheric Lesions of First-Ever Ischemic Stroke Patients. Ethnicity, 31, 44-30.

Lubis, N. D. A., Amelia, S., \& Balatif, R. (2020). Microbial Content Test on Sliced Papaya in Area of Universitas Sumatera Utara. Journal of Saintech Transfer, 3(2), 86-92.

Lubis, N. D. A., \& Sari, M. I. (2016, December). Body Mass Index and Triglyceride Levels of the Students of Faculty of Medicine University of North Sumatra 2016. In 1st Public Health International Conference (PHICo 2016). Atlantis Press.

Lubis, N. D. A., \& Lubis, H. A. P. (2016). Korelasi Indeks Massa Tubuh dengan Kebugaran Kardiorespirasi pada Siswa SMA Sutomo 2 Medan.

Lubis, N. D. A., Panggabean, M., \& Ichwan, M. (2020, November). Penguatan Sumberdaya Keluarga Dalam Mempercepat Perbaikan Gizi Masyarakat. In Talenta Conference Series: Agricultural and Natural Resources (ANR) (Vol. 3, No. 2).

Nasution, I. K., Lubis, N. D. A., Amelia, S., \& Hocin, K. (2018, March). The correlation of pain intensity and quality of life in chronic LBP patients in Adam Malik general hospital. In IOP Conference Series: Earth and Environmental Science (Vol. 125, No. 1, p. 012183). IOP Publishing.

Kusnadi, J. (2018). Pengawet Alami untuk Makanan. Universitas Brawijaya Press.

Amelia, S., Lubis, N. D. A., Balatif, R., Rozi, M. F., \& Sidhi, S. P. (2020, January). Antibacterial effect of Andaliman (Zanthoxylum acanthopodium) against contaminant in raw common carp (Cyprinus carpio Linnaeus). In IOP Conference Series: Earth and Environmental Science (Vol. 425, No. 1, p. 012036). IOP Publishing.

Amelia, S., Lubis, N. D. A., Rozi, M. F., \& Nababan, I. F. F. (2018, November). Safe processing method and storage time threshold for consuming of powdered-infant formula based on total plate count test. In IOP Conference Series: Earth and Environmental Science (Vol. 205, No. 1, p. 012033). IOP Publishing.

Amelia, S., Lubis, N. D. A., Siregar, M. A., \& Rozi, M. F. (2018). Research Article Antimicrobial Effect of Wasabia japonica or Wasabi on Raw Salmon in Served Sashimi at Japanese Restaurants in Medan.

Rosli, M. H. (2018). Korelasi Antara Status Gizi dan Status Anemia Terhadap Indeks Prestasi (IP) Mahasiswa Malaysia yang Studi di Universitas Sumatera Utara.

Lubis, N. D. A., \& Sari, M. I. (2016, December). Body Mass Index and Triglyceride Levels of the Students of Faculty of Medicine University of North Sumatra 2016. In 1st Public Health International Conference (PHICo 2016). Atlantis Press.

Lubis, N. D. A., Nasution, T. A., Wahyuni, D. D., \& Feriyawati, L. (2020, November). Gambaran Umum Status Kesehatan Siswa SDN 040494 Susuk Kecamatan Tiganderket, Kabupaten Karo. In Talenta Conference Series: Agricultural and Natural Resources (ANR) (Vol. 3, No. 2).

Lubis, N. D. A., Amelia, S., \& Balatif, R. (2020). Microbial Content Test on Sliced Papaya in Area of Universitas Sumatera Utara. Journal of Saintech Transfer, 3(2), 86-92.

LUBIS, N. D. A., NASUTION, T. A., \& PERMALU, R. K. LACK OF NUTRITION PROBLEM AMONG PRIMARY SCHOOL PUPILS IN MEDAN MUNICIPALITY

Amelia, S., Lubis, N. D. A., \& Balatif, R. (2020). Coliform Quality Test on Tofu Samples in Three Markets in Medan City. Systematic Reviews in Pharmacy, 11(5), 619-623.

Yusraini, E., \& Lubis, N. D. A. (2020). Partial properties of young corn flour based on particle size and its effect on texture and sensory acceptability of biscuit. E\&ES, 454(1), 012117.

Amelia, S., Lubis, N. D. A., Balatif, R., Rozi, M. F., \& Sidhi, S. P. (2020, January). Antibacterial effect of Andaliman (Zanthoxylum acanthopodium) against contaminant in raw common carp (Cyprinus carpio Linnaeus). In IOP Conference Series: Earth and Environmental Science (Vol. 425, No. 1, p. 012036). IOP Publishing.

Amelia, S., Lubis, N. D. A., Rozi, M. F., \& Nababan, I. F. F. (2018, November). Safe processing method and storage time threshold for consuming of powdered-infant formula based on total plate count test. In IOP Conference Series: Earth and Environmental Science (Vol. 205, No. 1, p. 012033). IOP Publishing.

Nasution, I. K., Lubis, N. D. A., Erwin, I., \& Nusa, M. I. (2018). Cognitive Function Differences based on Hemispheric Lesions of First-Ever Ischemic Stroke Patients. Ethnicity, 31, 44-30. 